Justyna Winiarska

Uniwersytet Jagielloński, Kraków

justyna.winiarska@uj.edu.pl

\title{
PLAKAT JAKO PRZYKŁAD MULTIMODALNEGO AMALGAMATU
}

\begin{abstract}
Słowa klucze: amalgamaty, integracja pojęciowa, komunikat multimodalny
Keywords: amalgams (conceptual blending), conceptual integration, multimodal communicate
\end{abstract}

Przedmiotem analizy w niniejszym tekście są dwa przykłady integracji pojęciowej wykorzystane w plakatach kampanii społecznych. Skondensowana forma przekazu, jaką wymusza plakat, mający za zadanie przekazać maksimum informacji szybko, w sposób prosty i jednocześnie atrakcyjny, stanowi znakomite miejsce wykorzystania sloganu czy hybrydy. Te zaś sięgają po kompozycję pojęć z różnych przestrzeni wyjściowych, aby stworzyć nową, przykuwającą uwagę i nośną informacyjnie całość. Twórcy teorii amalgamacji zakładają, że stapianie pojęć odbywa się na poziomie kognitywnym², a efekty tej operacji mogą być widoczne w postaci wyrażenia językowego lub tak zwanej materialnej kotwicy amalgamatu, czyli materialnego wytworu kultury, takiego jak obraz czy inne artefakty (Libura 2010: 76). Językoznawcza teoria amalgamacji dostarcza zatem narzędzia umożliwiającego spójny opis różnych aspektów multimodalnego komunikatu. Sądzę, że takie holistyczne podejście jest

1 Termin hybryda stosuje Agnieszka Libura (2010), dla której hybryda stanowi przykład generycznego amalgamatu, łączącego w jedno różne stworzenia, realizującego się w mitycznych postaciach sfinksa, centaura czy też fantastycznych stworzeniach wymyślanych współcześnie. Ja używam tego określenia w sposób bardziej tradycyjny - w odniesieniu do wizualnego amalgamatu, powstałego z graficznego połączenia dwu obrazów w nowy twór, niemający odpowiednika w świecie rzeczywistym, w którym bez trudu można dostrzec elementy dwu pierwotnych obrazów.

2 Por. „[...] postulujemy istnienie ogólnego procesu kognitywnego - jakim jest tworzenie konceptualnych amalgamatów" (Fauconnier, Turner 2001: 173) 
tym bardziej uzasadnione, iż językoznawstwo kognitywne zakłada istnienie silnych związków między językiem a doświadczeniem perceptualnym człowieka i sugeruje wręcz, że język i jego struktury mogą odzwierciedlać nasze doświadczenie percepcyjne, przede wszystkim wzrokowe ${ }^{3}$. W przypadku plakatu skutki integracji obserwujemy i na poziomie werbalnym - w wyniku czego powstaje slogan, i na poziomie wizualnym, gdzie graficzny amalgamat staje się skutecznym narzędziem wpływania na odbiorcę. Działa on tym skuteczniej, że odbiorcy trudno oceniać go w kategorii prawdy i fałszu, albowiem taki amalgamat „nie może właściwie kłamać”, gdyż nie ukrywa, że jest tylko konstrukcją, graficznym zabiegiem, retorycznym wizualnym chwytem ${ }^{4}$. Pod tym względem kampania społeczna przypomina reklamę, nieco bogatszy jest jednak świat przywoływanych przez nią emocji i wartości. Trzeba przyznać, że ze względu na perswazyjny charakter kampanii ich twórcy także dążą do upraszczania i ujednolicania wartościowania wewnątrz kreowanych przestrzeni dyskursu. Integracja przebiega zatem tak, aby usunąć niekorzystne dla przekazu emocje i wartościowanie, a wzmocnić te, które nadawca uznaje za korzystne. Nie jest to zawsze jednoznaczne $\mathrm{z}$ usuwaniem wartości negatywnych - na przykład w przypadku kampanii mających zniechęcić do jakichś zachowań przywoływane wartości i ewokowane emocje mogą być zdecydowanie negatywne, jak choćby w kampaniach przeciw paleniu tytoniu czy hodowli zwierząt futerkowych.

W plakatach stanowiących przedmiot obserwacji na szczególną uwagę zasługują wzajemne relacje słowa i obrazu - nie tylko uzupełniają się one nawzajem, ale też dokonują wzajemnych reinterpretacji5. Dopiero złożona konfiguracja dwu lub większej liczby zintegrowanych przestrzeni tworzy pełny przekaz komunikatu, jakim jest plakat. Stawia to przed badaczem pytanie o ilość i ewentualną odrębność przestrzeni wyjściowych uczestniczących w procesie integracji pojęć. Czy należy takie przestrzenie wyznaczać osobno dla sloganu i obrazu czy lepiej poszukać wspólnych przestrzeni wyjściowych? ${ }^{6}$ Należy też pamiętać, że w procesie uzupełniania struktury konstruowanego amalgamatu mogą być wykorzystywane dodatkowe przestrzenie mentalne i ramy kognitywne. Analizę utrudnia fakt, że dobry plakat nie stroni od gier słownych oraz od intersemiotycznych nawiązań.

3 Liczne argumenty na poparcie tej tezy, przytaczane przez różnych językoznawców, można znaleźć w książce Aliny Kwiatkowskiej (2013).

4 Por. uwagi Małgorzaty Lisowskiej-Magdziarz (2012), która opisując metafory wizualne w mediach masowych, dostrzega podobne zjawisko.

5 Postrzeganie relacji werbalny-wizualny jako opozycyjnych, co więcej - wymagających wskazania i udokumentowania wyższości jednego z kanałów - ma długą tradycję, omówioną choćby w pracy A. Kwiatkowskiej (2013). Jak przekonująco argumentuje autorka wspomnianej książki, podejście takie jest niesłuszne, a relacje słowo-obraz warto rozważać właśnie w kategoriach wzajemnych wpływów i interpretacji (Kwiatkowska 2013: 7).

6 Jak już wspomniałam, amalgamacja traktowana jest jako proces zachodzący na poziomie pojęciowym, a zatem werbalną lub obrazową formę amalgamatu można traktować jako zewnętrzny przejaw (i efekt) tego procesu. 
Przeprowadzone badania doprowadziły mnie do przekonania, że w całościowej analizie jednego komunikatu multimodalnego (werbalno-obrazowego), jakim jest plakat, warto poszukiwać przestrzeni wyjściowych wspólnych dla całego procesu integracji, następnie zaś wskazywać elementy tych przestrzeni, które uczestniczą w tworzeniu zintegrowanego wyrażenia językowego i obrazowej hybrydy. Obserwacje pokazują także, iż niejednokrotnie trzeba tu dostrzec więcej niż dwie przestrzenie wyjściowe. Taka złożona konfiguracja przestrzeni wyjściowych komplikuje wskazanie przestrzeni generycznej. Ponieważ w omawianych przykładach mamy do czynienia z nowymi, twórczymi amalgamatami, można przyjąć, że w skład przestrzeni generycznej wchodzą schematyczne struktury wyabstrahowane z pierwszej przestrzeni mentalnej, od której rozpoczęła się budowa amalgamatu7. Następnie struktury te pozwalają na dobór drugiej i ewentualnie kolejnej przestrzeni wyjściowej. Założenie to wymaga jednak weryfikacji i jest powiązane z szerszym i mocno kłopotliwym metodologicznie zagadnieniem: czym w ogóle są przestrzenie generyczne i na jakim stopniu szczegółowości (ogólności) należy ich poszukiwać ${ }^{8}$. Reasumując, w obu poniższych analizach proponuję przestrzenie wyjściowe (częściowo przynajmniej) wspólne dla amalgamatu słownego i obrazowego, a także staram się wskazać odpowiednie schematyczne przestrzenie generyczne. Mam jednak świadomość, że te ostatnie mogą być dyskusyjne.

Przyjrzyjmy się zatem pierwszemu przykładowi (Fot. 1) - jest to plakat opatrzony hasłem „Serca nie rosną na drzewach” stanowiący część kampanii społecznej zachęcającej do wypełniania tzw. deklaracji woli oraz szerzej - propagującej ideę przeszczepiania narządów (analogiczne plakaty i hasła promowały transplantację nerek i wątroby).

Plakat zdominowany jest przez obraz, którego uzupełnienie stanowi krótki tekst. Na czarnym tle widoczna jest hybryda kwiatu i serca. W plakacie wykorzystano realistyczny wizerunek mięśnia sercowego, nie zaś kulturowo umocowany i uproszczony jego symbol. Wynika to $\mathrm{z}$ chęci przywołania wyobrażenia autentycznego narządu. Drugą przestrzeń wyjściową hybrydowego obrazu stanowi prosty kwiat składający się jedynie z łodygi i kielicha w pąku. Przypomina on mak, a drobne włoski pokrywają nie tylko łodygę, ale i tę część kielicha, którą de facto stanowi część mięśnia sercowego. Dzięki nim obraz łodygi i serca-kielicha zostaje jeszcze mocniej

7 Jeśli przyjąć porządkującą klasyfikację A. Libury (2010: 84), choć relacje między przestrzeniami wyjściowymi i przestrzenią generyczną są różnie postrzegane.

8 Niektórzy językoznawcy, przedstawiając teorię stapiania, traktują sprawę przestrzeni generycznych bardzo swobodnie (np. Lewandowska-Tomaszczyk 2006) i uchylają się od ich wskazywania. Podobnie postępują też niekiedy sami twórcy tej teorii - przykłady można znaleźć choćby $\mathrm{w}$ The Way We Think (Fauconnier, Turner 2003: 65-67). Z kolei autorzy analiz zawartych w tomie Amalgamaty kognitywne w sztuce (2007) znajdują przestrzenie generyczne zawierające elementy wysoce schematyczne takie jak agens, działanie, cel, pozycja (Kosiński 2007: 110) lub przeciwnie, bardzo uszczegółowione: Chrystus, ludzie, krajobraz, pomocnik (Kaźmierska 2007: 117) 
zintegrowany. Wykorzystanie na plakacie akurat maku może wynikać z symboliki tego kwiatu9. Według słownika Kopalińskiego (2012) mak symbolizuje między innymi sen i zmartwychwstanie, a wielowymiarowa symbolika jest obecna już w starożytnej mitologii, która w makowym wieńcu przedstawiała choćby boga śmierci Tanatosa. Uwzględniając również to, że mak uznawany był za symbol nie tylko śmierci, ale i pocieszenia (mit Kory i Demeter), łatwo zauważyć, że takie nawiązania wzbogacają przekaz plakatu i współgrają z tematem przeszczepu, nierozerwalnie związanym z umieraniem i nadzieją na nowe życie.

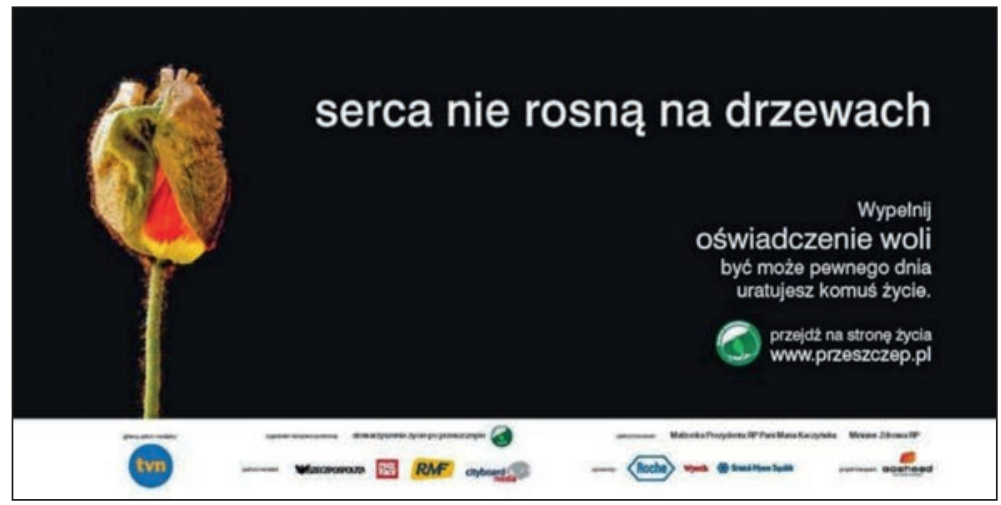

Fot. 1. Kampania społeczna zachęcająca do wypełniania deklaracji woli.

Wtopienie obrazu mięśnia sercowego w kielich kwiatu sprzyja estetyzacji tego pierwszego, co ma duże znaczenie w wypadku kampanii mającej na celu przekonywanie do przekazywania narządów na przeszczep (a mówiąc szerzej: dążącej do zbudowania pozytywnie nacechowanego obrazu całej tej domeny kognitywnej, która sama $z$ siebie budzi raczej lęk i inne negatywne emocje). Sądzę, że wygląd jest jednym z powodów, dla których zdecydowano się na wizualne stopienie narządu $\mathrm{z}$ kwiatem, wbrew obrazowi sugerowanemu w sferze werbalnej (serca rosnące na drzewach). Kwiat - taki jak wykorzystany tu mak - waloryzowany jest pod względem wyglądu wyłącznie pozytywnie. Narządy wewnętrzne natomiast, nawet jeśli nie budzą odrazy, nie są z pewnością przez niespecjalistów (tj. osoby niebędące lekarzami) postrzegane jako coś ładnego. Dochodzimy tu do zasadniczego dla naszych rozważań faktu - jednym z celów analizowanego amalgamatu jest „oswojenie” na różnych poziomach tematyki przeszczepów i świadomego przekazywania narządów innym ludziom. Osiągnięciu tego celu znakomicie służy to, co stanowi wręcz istotę integracji pojęciowej - stworzenie prostej historii z bezpośrednią przyczynowością i dzięki temu osiąganie bliskiego człowiekowi wymiaru doświadczenia oraz transfer emocji (w tym wypadku pozytywnych) do zintegrowanej struktury.

9 Za zwrócenie na to uwagi bardzo dziękuję Recenzentowi artykułu. 
W tym momencie możemy wskazać dwie przestrzenie wyjściowe, a kolejna ujawni się podczas analizy strony werbalnej plakatu. Przestrzeń W1 - nazwijmy ją Przestrzenią przeszczepu - obejmuje potoczną wiedzę na temat przeszczepiania narządów. Składają się na nią z jednej strony obraz narządu, z drugiej czerpany zasadniczo z mediów (telewizji) dość schematyczny obraz zespołu lekarzy i samej procedury przenoszenia narządu od osoby zmarłej do pacjenta. Ponadto przestrzeń ta nacechowana jest silnymi emocjami - wewnątrz kognitywnej ramy przeszczepu funkcjonują co prawda szpital i ratowanie życia, ale dominują negatywne odczucia - takie jak lęk, smutek z powodu czyjejś śmieci oraz ból fizyczny i psychiczny. Przestrzeń ta (W1) podlega na plakacie dwojakiej reinterpretacji. Pierwsza z nich dokonuje się dzięki materialnej kotwicy, czyli obrazowi kwiatu-serca, druga, o której za moment, rozgrywa się na płaszczyźnie werbalnej. Przywołana przez graficzną hybrydę przestrzeń kwiatów (W2) obejmuje ich estetyczny wygląd oraz - w wypadku rozpoznania przedstawionego na plakacie kwiatu jako maku - może nieść dodatkowe, wyżej wymienione sensy. Ponadto podczas procesu integracji powstający amalgamat (A1) zostaje uzupełniony kognitywną ramą obdarowywania. W jej obrębie funkcjonują dwie osoby, z których jedna osobiście i bezpośrednio ofiarowuje drugiej prezent. Dominują tu zasadniczo pozytywne emocje, takie jak radość, a dawany przedmiot (np. kwiat) może być wyrazem sympatii czy wdzięczności. Dzięki takiemu uzupełnieniu w przestrzeni amalgamatu (A1) przeszczep może być przedstawiony jako świadome i bezpośrednie podarowanie komuś prezentu. Z ramy obdarowywania ulegają transferowi również pozytywne emocje, natomiast walory estetyczne zawdzięcza podarunek przestrzeni kwiatów (W2). Wewnątrz amalgamatu (A1) pojawia się także nowy agens - żywy i świadomy dawca ${ }^{10}$.

Jak wspomniano, na przestrzeń W1 (realną procedurę przeszczepu) składają się działania co najmniej kilku lekarzy, obecne są w niej intensywne negatywne emocje związane z bólem, cierpieniem, śmiercią, a estetyczna strona pobierania i wszczepiania narządu jest co najmniej niejednoznaczna, brakuje też jasnej i prostej intencjonalności, ponieważ dawca nie może tak naprawdę nikogo obdarować - nie żyje i nie podejmuje żadnych świadomych działań. Te elementy nie ulegają jednak transferowi do przestrzeni amalgamatu i dzięki temu w zintegrowanej przestrzeni udaje się zupełnie zmienić ten negatywny obraz i osiągnąć wymiar bliski codziennemu doświadczeniu. Gilles Fauconnier i Mark Turner niejednokrotnie podkreślali wartość stworzenia prostej historii o jasnej przyczynowości i niewielkiej liczbie uczestników (np. Fauconnier, Turner 2003: 322-324). Taką właśnie napotykamy w amalgamacie

10 Zauważmy, że świadomy dawca może istnieć w przestrzeni realnej. To właśnie ktoś, kto za życia wypełni deklarację woli. Obserwujemy tu zatem właściwą amalgamatom możliwość transferu wnioskowania ze zintegrowanej przestrzeni do jednej z przestrzeni wyjściowych. Takim kimś może się stać odbiorca plakatu, do którego skierowane są słowa „wypełnij oświadczenie woli; być może któregoś dnia uratujesz komuś życie”. 
serca-kwiatu ${ }^{11}$. To dawca świadomie, intencjonalnie podarowuje komuś narząd, nie ma tu pośredniczących zespołów lekarzy i specjalistów. Transferowi z przestrzeni prawdziwego przeszczepu nie ulegają także negatywne emocje i estetyka.

Przyjrzyjmy się teraz bliżej konstrukcji sloganu „Serca nie rosną na drzewach”, który, jak wspomniałam, dokonuje kolejnej reinterpretacji przestrzeni medycznej (W1). Na poziomie pragmatycznym jego działanie można wyjaśnić odwołując się do Grice'owskich maksym konwersacyjnych. Naruszenie maksymy ilości, czym jest wygłoszenie jawnego truizmu, implikuje wówczas trudnodostępność serc-narządów. Skąd jednak pochodzi ów element (trudno)dostępności? Kluczem okazuje się przecząca forma sloganu. Uruchamia ona kontrfaktyczną przestrzeń mentalną (W4), która może zostać wykorzystana do lepszego zrozumienia innej przestrzeni i do przeprowadzania w niej wnioskowania. Jak zauważyli Fauconnier i Turner, „negacja rutynowo ustanawia kontrfaktyczną przestrzeń w amalgamacie, a przestrzeń ta może być następnie szczegółowo dopracowywana" (2003: 239) ${ }^{12}$. Zanim jednak się ona pojawi, przywołana musi zostać przestrzeń wyjściowa $\mathrm{W}_{3}$ - nazwijmy ją Przestrzenią zbierania owoców z drzew. Przestrzeń ta, znów oparta na potocznej, zdroworozsądkowej wiedzy, zawiera obraz drzew, z których można w razie potrzeby (np. głodu) zerwać owoc, w naszej kulturze zapewne jest to prototypowe jabłko. Pomiędzy elementami tej przestrzeni oraz elementami W1 zostają ustanowione odpowiednie relacje. Funkcjonujące w przestrzeni W1 serce, w którym w tym wypadku profilowane są takie aspekty jak 'potrzebne', 'brakujące', łączy analogia z owocem na drzewie. Podobna relacja łączy też zrywanie owocu i pobieranie serca od dawcy. Relacja dysanalogii łączy natomiast wielość (dostępność) owoców i jednostkowość (unikatowość) serca-narządu. W wyniku integracji przestrzeni W1 i W3 wyłania się pośrednia kontrfaktyczna przestrzeń $\mathrm{W}_{4}$, w której dochodzi do kompresji elementów analogicznych - a zatem w przestrzeni tej serca rosną na drzewach, czyli są stosunkowo łatwo dostępne. Przestrzeń ta pojawia się jedynie w tle i zostaje przywołana dzięki użyciu operatora negacji w plakatowym sloganie. Właściwa przestrzeń sloganu to przestrzeń „negatywna” - przestrzeń braku, w której serca właśnie nie rosną na drzewach i dla potrzebujących biorców ich brakuje. To ona ujawnia się na plakacie. Pamiętajmy jednak, że jej rozumienie jest możliwe dzięki pozostającej w tle przestrzeni kontrfaktycznej W4. W przypadku mówienia o braku brakująca rzecz zyskuje swoją „rzeczowość” właśnie dzięki przywołaniu w tle przestrzeni, w której jest ona rzeczą ${ }^{13}$.

Reasumując, można stwierdzić, że w budowaniu przekazu plakatu uczestniczy kilka przestrzeni mentalnych, wzajemnie powiązanych. Centralne miejsce zajmu-

11 Określam go tym mianem, choć mam tu na myśli całą zintegrowaną werbalno-wizualną konstrukcję.

12 „[...] negation routinely sets up counterfactual blended spaces, which can be elaborated" [tłum. J.W.]

13 Autorzy The Way We Think omawiają wyrażenie „brakujące krzesło”, które w amalgamacie jest rzeczą, a "postrzegane z zewnątrz" jest nie-rzeczą (Fauconnier, Turner 2003: 241). 
je przestrzeń przeszczepiania narządów W1, której elementy wchodzą w relacje zarówno z przestrzenią kwiatów W2, zasilającą obraz (i, pośrednio, słowne wezwanie odbiorcy do wypełnienia deklaracji woli, które uczyni go świadomym dawcą), jak i z przestrzenią zrywania owoców z drzew $\left(\mathrm{W}_{3}\right)$. Abstrahuję tu chwilowo od przestrzeni $\mathrm{W}_{4}$, ponieważ wynika ona ze specyfiki użytej w haśle negacji. Natomiast istnienie jednej przestrzeni wspólnej, której elementy uczestniczą w procesach integracji z dwiema innymi przestrzeniami wyjściowymi, jedną wykorzystaną w budowaniu hybrydowego obrazu, drugą zaś w budowaniu werbalnej warstwy komunikatu, wydaje mi się charakterystyczne dla integracji pojęciowej leżącej u podłoża złożonych multimodalnych komunikatów takich jak plakat. Wydaje się to zresztą logiczne, gdyż istnienie jednej bogato ustrukturyzowanej przestrzeni, której różne elementy mogą wchodzić w relacje z elementami różnych innych przestrzeni wyjściowych, służy z całą pewnością zapewnieniu spójności złożonego komunikatu.

$\mathrm{Na}$ koniec podejmijmy jeszcze próbę wskazania przestrzeni generycznych. Jak pamiętamy, w tworzeniu tego komunikatu uczestniczą trzy przestrzenie wyjściowe. Pierwszym etapem wydaje się zatem wskazanie nadrzędnych schematycznych przestrzeni generycznych dla W1 i W2 (zasilających obraz) oraz dla $W_{1}$ i W3 (zasilających slogan). Są to odpowiednio: „Obiekt” dla W1 i W2 oraz schemat: „Ktoś coś skądś zabiera" dla W1 i W3. Następnie możemy zaproponować wspólną dla całego procesu integracji przestrzeń generyczną w postaci schematu: „Agens, obiekt, proces". Całość omówionych wyżej relacji między różnymi przestrzeniami mentalnymi ilustruje schemat 1.

Poświęćmy teraz chwilę uwagi drugiemu plakatowi (Fot. 2.), który też jest elementem szerszej kampanii, tym razem antynikotynowej. Pragmatycznym celem jest tu - przeciwnie niż w poprzednim przykładzie - zniechęcenie do pewnych zachowań, jednak zastosowane podczas konstrukcji przekazu strategie są bardzo podobne.

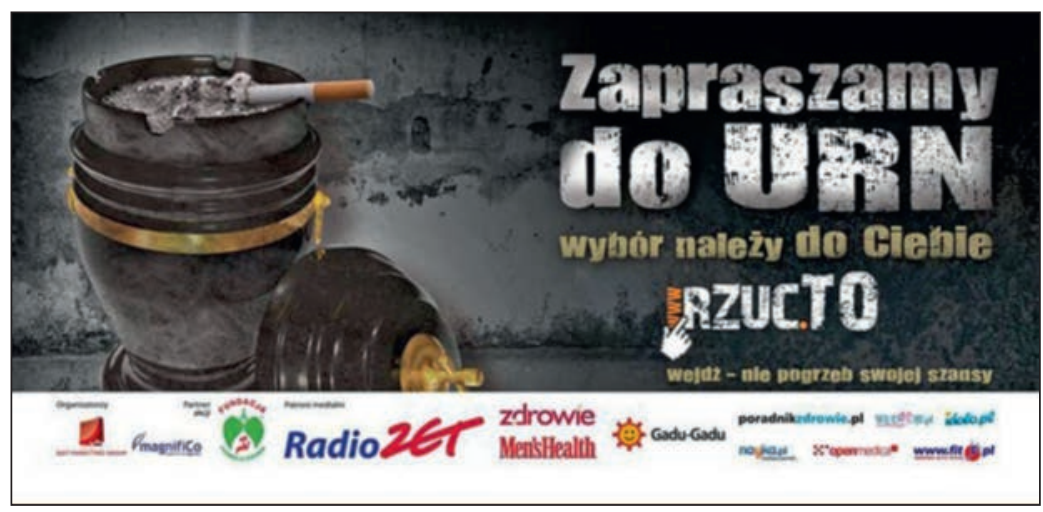

Fot. 2. Kampania społeczna antynikotynowa. 


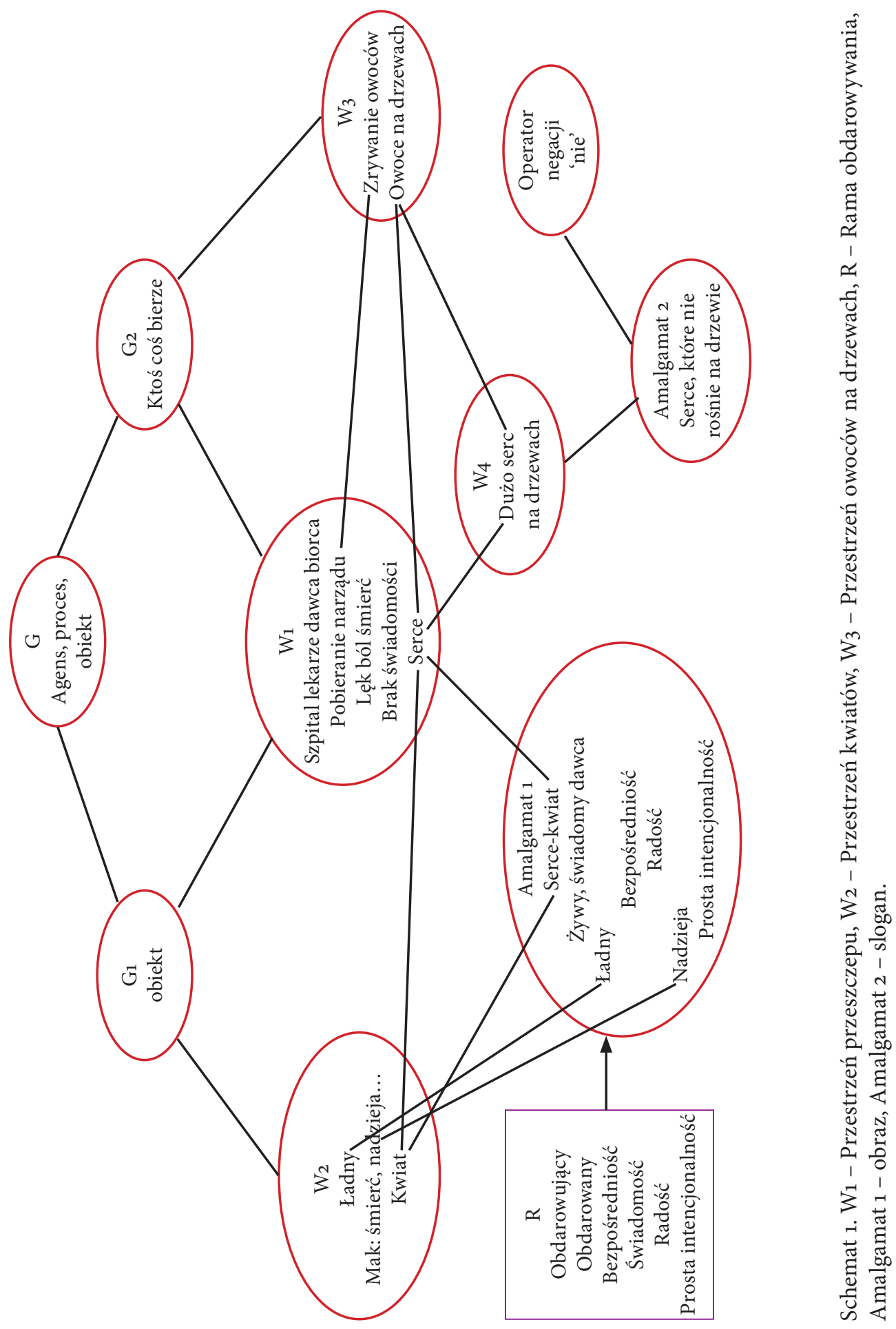


Czarnopopielatą przestrzeń plakatu dzielą mniej więcej po równo obraz i hasło, tworzące jeden komunikat i wzajemnie się interpretujące, przy czym zrozumienie obrazu wymaga od odbiorcy chwili uwagi, natomiast hasło: „Zapraszamy do urn” wydaje się na pierwszy rzut oka oczywiste. Pierwsza („wyborcza”) interpretacja okazuje się jednak niesłuszna i zostaje zweryfikowana przede wszystkim pod wpływem obrazu, ale i dalszego tekstu, mianowicie zachęty do odwiedzenia strony internetowej: „Wejdź. Nie pogrzeb swojej szansy”. Dość złożoną stroną werbalną plakatu zajmiemy się jednak dokładniej w dalszej części artykułu, a teraz przyjrzyjmy się obrazowi.

Przedstawia on połączenie urny pogrzebowej i popielniczki z widocznym popiołem i tlącym się papierosem. Naczynie wykonano z jednolitego marmuru i stanowi ono niepodzielną całość. Wraz z integracją obrazów dokonała się integracja dwu przestrzeni wyjściowych, między ich elementami ustanowiono relacje analogii i dysanalogii, a w procesie amalgamacji doszło do kompresji tych i innych relacji. Wyłaniające się w zintegrowanej przestrzeni wnioski mogą być następnie transferowane do jednej z przestrzeni wyjściowych.

Zobaczmy, jak w szczegółach przebiega ten proces. Centralna dla plakatu przestrzeń W1 (Przestrzeń palenia papierosów) zawiera popielniczkę, popiół z papierosa i sam papieros, a także domyślnie (papieros tli się odłożony na chwilę) kogoś, kto go pali. Przestrzeń W2 (Przestrzeń pogrzebu) zawiera obraz urny i prochów, a także wiedzę o pochodzeniu tych prochów, a więc o tym, że jest to pozostałość po spaleniu ciała zmarłej osoby. Relacja analogii łączy urnę i popielniczkę, prochy i popiół, a także może zostać ustanowiona między tym, co spalane, a więc papierosem i ludzkim ciałem. Relacja dysanalogii łączy palacza - żywego agensa i ludzkie ciało poddane procesowi kremacji. Zatem w zintegrowanej przestrzeni prochy są jednocześnie popiołem, a urna jest jednocześnie popielniczką, co znalazło realizację graficzną. W wyniku kompresji ludzkie ciało spala się wraz z paleniem papierosa, a relacja dysanalogii zostaje skompresowana do zmiany żywego palacza w martwe ciało ulegające spaleniu. W zintegrowanym obrazie palenie papierosa zabija - spalony tytoń staje się jednocześnie spalonym ludzkim ciałem. Nastąpiła tu zatem także kompresja czasu i przyczynowości. W rzeczywistym świecie, nawet jeśli badania wykazały związek między paleniem papierosów a śmiertelnością, jest to proces rozciągnięty w czasie i pozbawiony jednoznacznej przyczynowości - naukowo można jedynie wykazać, że palenie statystycznie zwiększa ryzyko zachorowania na śmiertelne choroby. Obraz $\mathrm{w}$ amalgamacie ustanawia jednoznaczną relację przyczynową i skraca czasowy dystans z przestrzeni wyjściowej W1 - palić można wiele lat, a w zintegrowanej przestrzeni palenie powoduje natychmiastowe unicestwienie. Ten właśnie jednoznaczny wniosek „Palisz - zabijasz siebie” może zostać przetransponowany i wykorzystany do rozumowania $\mathrm{w}$ przestrzeni $\mathrm{W} 1$, znanej realnemu palaczowi $\mathrm{z}$ doświadczenia. Tak drastyczny przekaz służyć ma osiągnięciu perswazyjnego celu kampanii. 
Zrozumienie (rozpakowanie) wizualnego amalgamatu powoduje reinterpretację hasła „Zapraszamy do urn”, które okazują się urnami pogrzebowymi. Uruchomiona jednak przez slogan przestrzeń wyborów demokratycznych nie zostaje całkowicie zanegowana. Wykorzystano ją w kolejnej - apelatywnej warstwie plakatu. Tak bowiem jak w warstwie wizualnej plakat stara się do palenia zniechęcić, tak w warstwie werbalnej zachęca do działania - dokonania wyboru, zaprzestania palenia. Służy temu po pierwsze zwrot do odbiorcy „wybór należy do ciebie”, a po drugie wskazanie sposobu postępowania - zaproszenie do odwiedzenia internetowego serwisu społecznościowego skierowanego do osób, które chcą zerwać z nałogiem nikotynowym. Zaproszenie to sformułowano „Wejdź. Nie pogrzeb swojej szansy”. Adres strony, również oparty na grze słownej, brzmi: www.rzuc.to.

Jakie zatem przestrzenie uczestniczą w powstaniu werbalnej warstwy plakatu? Niewątpliwie pojawia się tu nowa przestrzeń W3, nazwijmy ją „Przestrzenią wyborów (głosowania)”. Została ona po raz pierwszy uaktywniona w wezwaniu „zapraszamy do urn", choć, jak widzieliśmy, podlega później przewrotnej interpretacji. Gdy po rozpakowaniu wizualnego amalgamatu okazuje się, o jakie urny chodzi autorom kampanii, w werbalnej sferze dokonuje się kolejna wolta i znów pojawia się przestrzeń głosowania. To ze skryptu wyborów demokratycznych pochodzi wzywanie do podejmowania decyzji (podczas głosowania) oraz akt wrzucania głosu do urny. Drugą aktywną tu przestrzenią jest niewątpliwie przestrzeń palenia papierosów W1. W wyniku transferu wybranych elementów z W1 i W3 powstała zintegrowana struktura, wewnątrz której pojawił się kalambur. Potoczne określenie zrywania z nałogiem - „rzucanie palenia” uczestniczy w utworzeniu nazwy internetowej domeny www.rzuc.to, w której rzucanie jest jednocześnie wrzuceniem głosu, czyli podejmowaniem decyzji.

Nieco inaczej sprawa ma się z ostatnim werbalnym elementem plakatu, wezwaniem „nie pogrzeb swojej szansy”. Dzięki przywołanej już przez obraz przestrzeni pogrzebu we frazeologizmie uruchomiono w tym miejscu niemetaforyczne znaczenie czasownika „pogrzebać”. W tej części hasła nie wykorzystano zatem przestrzeni $\mathrm{W}_{3}$, tylko $\mathrm{W}_{2}$.

A jakie przestrzenie generyczne ma się wskazać w tym przypadku? Sądzę, że dla przestrzeni W1 i W2 (zasilających obraz i jedno $z$ haseł) jest to ogólny schemat „ktoś coś spala/pali”, natomiast dla przestrzeni W1 i W3 (uczestniczących w tworzeniu prawie całej warstwy werbalnej plakatu) jest to schemat „ktoś coś wybiera / ktoś o czymś decyduje". Wspólna dla całego plakatu przestrzeń generyczna obejmuje w tym przypadku agensa, celowe działanie i zmianę. Relacje między wszystkimi przestrzeniami mentalnymi wykorzystanymi w tym plakacie ilustruje schemat 2. 


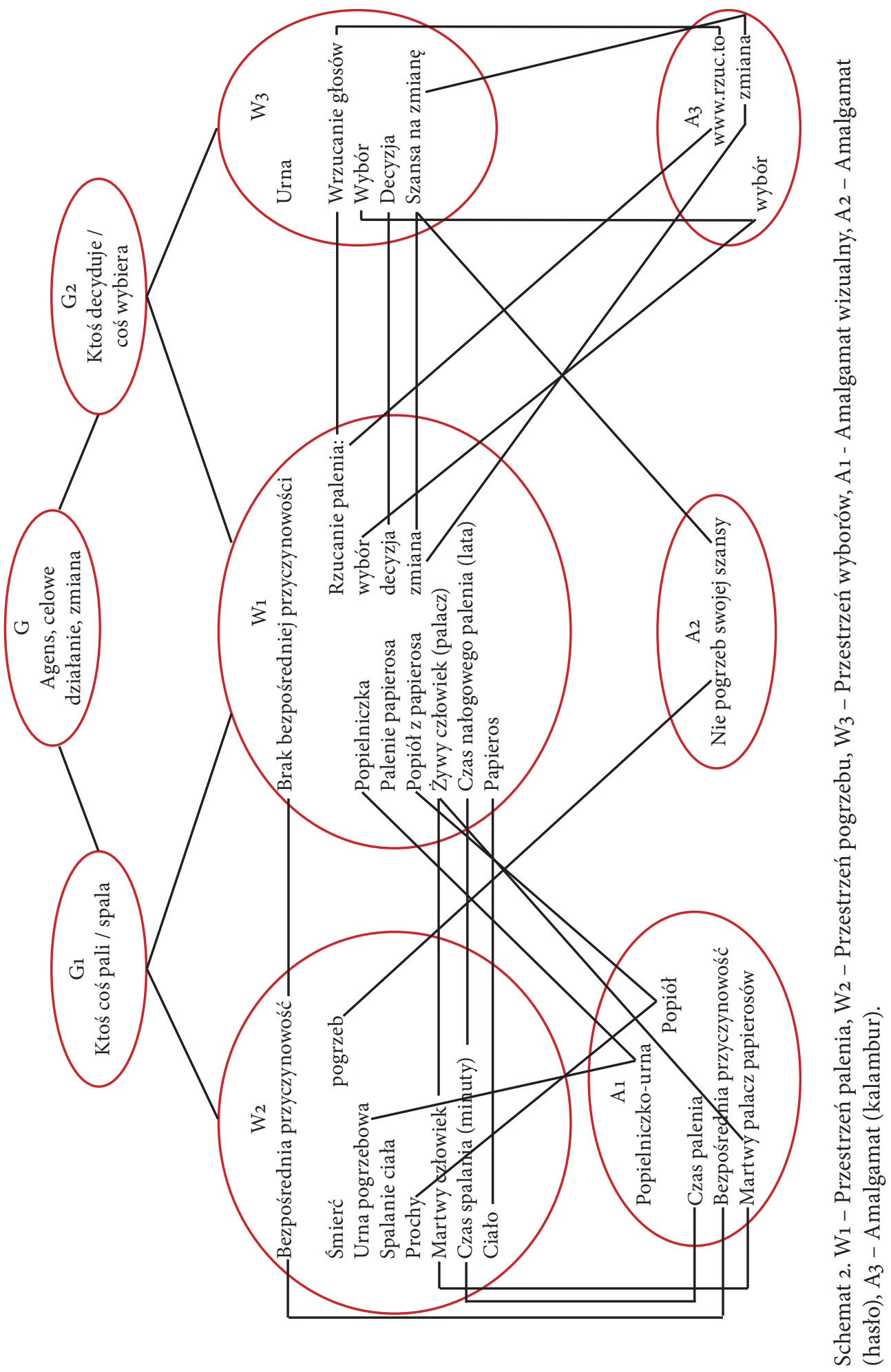


Jak sądzę, powyższa analiza ukazała niezwykle ścisły związek między werbalną i wizualną warstwą plakatów. Właściwe odczytanie przesłania kampanii jest możliwe dzięki interpretacji obu tych warstw oraz uchwyceniu przez odbiorcę ich reinterpretacji, dokonujących się w wyniku ich wzajemnego oddziaływania. Teoria przestrzeni mentalnych oraz integracji pojęciowej oferuje narzędzie umożliwiające jednolity opis budowania i rozumienia komunikatu na obu tych płaszczyznach. Pomaga wskazać przestrzenie wyjściowe dla zintegrowanej struktury, z jaką spotyka się odbiorca. Z kolei świadomość, że wnioskowanie dokonywane wewnątrz amalgamatu może być następnie transferowane do jednej z przestrzeni wyjściowych, pomaga zrozumieć, w jaki sposób „hybrydowe” obrazy i hasła mają kształtować u odbiorcy rozumienie jednej z przestrzeni wyjściowych, mianowicie tej, o której przekształcenie chodzi autorom kampanii.

\section{Literatura}

FAUCONnier G., Turner M., 2001, Tworzenie amalgamatów jako jeden z głównych procesów w gramatyce, [w:] W. Kubiński, D. Stanulewicz (red.), Językoznawstwo kognitywne II, tłum. W. Kubiński, D. Stanulewicz, Gdańsk, s. 173-201.

Fauconnier G., Turner M., 2003, The Way We Think. Conceptual Blending and the Mind's Hidden Complexities, New York.

KAźMIERsKa E., 2007, „Golgota Jasnogórska” Jerzego Dudy-Gracza. Stapianie pojęć w siatkach wielozakresowych, [w:] A. Libura (red.), Amalgamaty kognitywne w sztuce, Kraków, s. $113-126$.

Kopaliński W., 2012, Słownik symboli, Warszawa.

KosıŃski M., 2007, Teoria metafory pojęciowej a teoria amalgamatów. Rozważania na marginesie analizy „Głosu w sprawie pornografii” Wisławy Szymborskiej, [w:] A. Libura (red.), Amalgamaty kognitywne w sztuce, Kraków, s. 95-112.

Kwiatкоwsка A., 2013, Interfaces, Interspaces. Image - Language - Cognition, Piotrków Trybunalski.

Lewandowska-Tomaszczyк B., 2006, Konstruowanie znaczeń i teoria stapiania, [w:] G. Habrajska, J. Ślósarska (red.), Kognitywizm w poetyce i stylistyce, Kraków, s. 7-35.

Libura A., 2010, Teoria przestrzeni mentalnych i integracji pojęciowej, Wrocław.

Lisowska-Magdziarz M., 2012, Obrazy ciała, obrazy produktu. Analiza metafor wizualnych i multimodalnych $w$ mediach masowych, [w:] P. Francuz (red.), Komunikacja wizualna, Warszawa, s. 103-129. 


\section{Poster as an example of a multimodal amalgam (conceptual blend) Summary}

The author analyses two posters used in two social campaigns. Posters are unique in their usage as means of communication because they aim to provide information quickly and in an eye-catching way. As a result, their authors often use conceptual blending and integration to create persuasive communication. In the article, the author treats posters as complex blends, she finds input spaces, indicates relations between their elements, and tries to discover generic spaces on different levels of specificity. This methodology enables her to show how a complex verbal and visual statement can be coherently understood by the viewer. 